\title{
1.2 Складання та подання фінансової звітності підприємствами України на основі таксономії фінансової звітності за міжнародними стандартами
}

Обраний Україною курс на інтеграцію у європейську економічну спільноту вимагає від усіх вітчизняних учасників фінансово-економічних відносин рішучих дій у напрямку гармонізації і стандартизації ведення обліку, складання фінансової звітності та проведення аудиту.

Завершальним етапом ведення обліку на підприємстві $є$ складання фінансової звітності, яка містить необхідну інформацію про фінансовий стан підприємства, його фінансові результати, рух грошових коштів внаслідок здійснення різних видів діяльності, а також зміни у власному капіталі. Для того, щоб показники фінансової звітності українських підприємств були зрозумілі та інформативні не лише для вітчизняних, але і для іноземних користувачів інформації важливим $є$ відповідність iï складання вимогам міжнародних стандартів фінансової звітності (МСФЗ).

На сьогодні фінансову звітність та консолідовану фінансову звітність за МСФЗ складає ряд підприємств (дана вимога закріплена у Законі України «Про бухгалтерський облік та фінансову звітність в Україні» від 16.07.1999 р. № 996XIV), до яких належать:

1) підприємства, що становлять суспільний інтерес - це суб'єкти господарювання-емітенти цінних паперів, цінні папери яких котируються на фондових біржах або щодо даних цінних паперів здійснено публічну пропозицію; банківські установи; страхові компанії; недержавні пенсійні фонди; інші фінансові установи та підприємства, які відповідно до ст. 1 цього Закону належать до великих підприємств.

Великими підприємствами вважаються такі, показники яких на дату складання річної фінансової звітності відповідають щонайменше двом із наступних критеріїв:

- балансова вартість активів - понад 20 млн. євро; 
- чистий дохід від збуту продукції (товарів, робіт, послуг) - понад 40 млн. євро;

- чисельність працівників - понад 250 осіб;

2) публічні акціонерні товариства;

3) суб'єкти господарювання, які здійснюють діяльність у видобувних галузях;

4) підприємства, які провадять господарську діяльність за напрямками, перелік яких визначається Кабінетом Міністрів України:

- надання фінансових послуг, крім страхування та пенсійного страхування;

- недержавне пенсійне страхування;

- допоміжна діяльність у сферах фінансових послуг і страхування за винятком допоміжної діяльності у сфері страхування та пенсійного страхування [14].

Відповідно до вимог законодавства фінансова звітність вищевказаних підприємств України, повинна бути підготовлена згідно з таксономією, зокрема Таксономією UA XBRL міжнародних стандартів фінансової звітності, і подана в єдиному електронному форматі.

Розглянемо і більш детальніше розберемося в основних поняттях, які супроводжують даний процес.

Таксономія - це класифікаційна система, яка може бути використана для ідентифікації та структурування інформації з метою полегшення іiї пошуку та обробки користувачем [15].

Таксономія фінансової звітності - це склад статей і показників фінансової звітності та ії елементів, які підлягають розкриттю [15].

Система таксономії МСФЗ:

1) перераховує і визначає конкретні коди, якими можна скористатися для ідентифікації інформації, розкритої у фінансовій звітності за МСФЗ;

2) включає зміст, який описує значення елемента бухгалтерського обліку або допомагає користувачу знайти правильний елемент. 
Окрім цього, у таксономії містяться елементи розкриття інформації, які не вимагаються спеціально МСФЗ, але зазвичай розкриваються на практиці.

Таксономія UA XBRL MCФ3 - це таксономія фінансової звітності за міжнародними стандартами фінансової звітності в Україні, затверджена Міністерством фінансів України, яка адаптована до особливостей складання фінансової звітності в Україні та включає в себе також звіт аудитора і звіт про управління.

Для забезпечення виконання вимог Законів України «Про бухгалтерський облік та фінансову звітність в Україні» [14] і «Про внесення змін до Закону України «Про бухгалтерський облік та фінансову звітність в Україні» щодо удосконалення деяких положень» від 05.10 .2017 p. № 2164-VIII [18] Міністерство фінансів України відповідно до Договору з Фондом міжнародних стандартів фінансової звітності (м. Лондон, Велика Британія) отримує текст таксономії фінансової звітності за міжнародними стандартами мовою оригіналу, здійснює його переклад та оприлюднює на офіційному веб-сайті.

3 метою проведення підготовчих заходів щодо подання фінансової звітності на основі таксономії фінансової звітності за міжнародними стандартами в єдиному електронному форматі Міністерством фінансів України, Національною комісією з цінних паперів та фондового ринку, Національним банком України та Національною комісією, що здійснює державне регулювання у сфері ринків фінансових послуг у 2017 р. підписано Меморандум про взаєморозуміння щодо розробки і запровадження системи фінансової звітності [17]. У 2019 році до Меморандуму долучено Державну службу статистики України, Державну податкову службу України та Орган суспільного нагляду за аудиторською діяльністю. Згідно з Меморандумом [17] запроваджується єдина Система фінансової звітності (СФЗ) як інтегрована система, що дозволяє отримувати, перевіряти, обробляти та розкривати фінансову звітність суб'єктів звітування та ïx аудиторських звітів на основі використання документів у форматі Inline XBRL (iXBRL):

- в уніфікованому електронному форматі iXBRL; 
- підготовленої відповідно до таксономії UA XBRL MCФЗ;

- за принципом «єдиного вікна» [20].

iXBRL - це технологія, яка забезпечує механізм вбудовування тегів XBRL у документи HTML, що дозволяє отримати переваги відмічених (протегованих) XBRL-даних у поєднанні зі зручною для читання презентацією звіту [21].

Наказом Міністерства фінансів України «Про затвердження перекладу Таксономії фінансової звітності за міжнародними стандартами фінансової звітності» від 13.11.2020 р. № 709 [19] передбачено, що фінансова звітність на основі Таксономії фінансової звітності за МСФЗ складається і подається в єдиному електронному форматі із застосуванням розширюваної мови ділової звітності (XBRL).

Формат є XBRL (англ. eXtensibleBusiness Reporting Language «розширювана мова ділової звітності») - відкритий стандарт обміну діловою інформацією, який широко використовується в світовій практиці [20]. Використання формату XBRL несе численні переваги як для суб' єктів звітування, держави, так і для інвесторів (рис. 1.2.1).

Формат XBRL запроваджується у світі для посилення підзвітності та прозорості результатів діяльності підприємств, забезпечуючи відкритий стандарт обміну бізнес-інформацією.

Для того, щоб подавати фінансову звітність у форматі іXBRL підприємству необхідно здійснити такі кроки:

1. Зареєструватися на порталі СФЗ.

2. Скласти фінансову звітність відповідно до Таксономії МСФЗ у форматі iXBRL.

Таксономія UA XBRL MCФЗ надає можливість обрати один з двох варіантів складання фінансової звітності для суб'єктів господарювання (за виключенням банків) (рис. 1.2.3). 
Переваги застосування XBRL при складанні фінансової звітності

\section{для суб'сктів звітування}

1) коректне складання фінансової звітності;

2) виключення дублювання при поданні фінансової звітності регуляторам

3) сприяння залученню інвесторів

\section{для держави}

1) швидкість i автоматичність обробки та аналізу фінансової звітності;

2) своєчасне виявлення ризиків i оперативне реагування на них;

3) ефективний та економічний регуляторний процес

\section{для інвесторів}

1) якісне розкриття інформації за МСФ3;

2) швидкість та автоматичність обробки та аналізу фінансової звітності;

3) краще розуміння ризиків i перспектив бізнесу

Рис. 1.2.1. Переваги застосування XBRL при складанні фінансової звітності

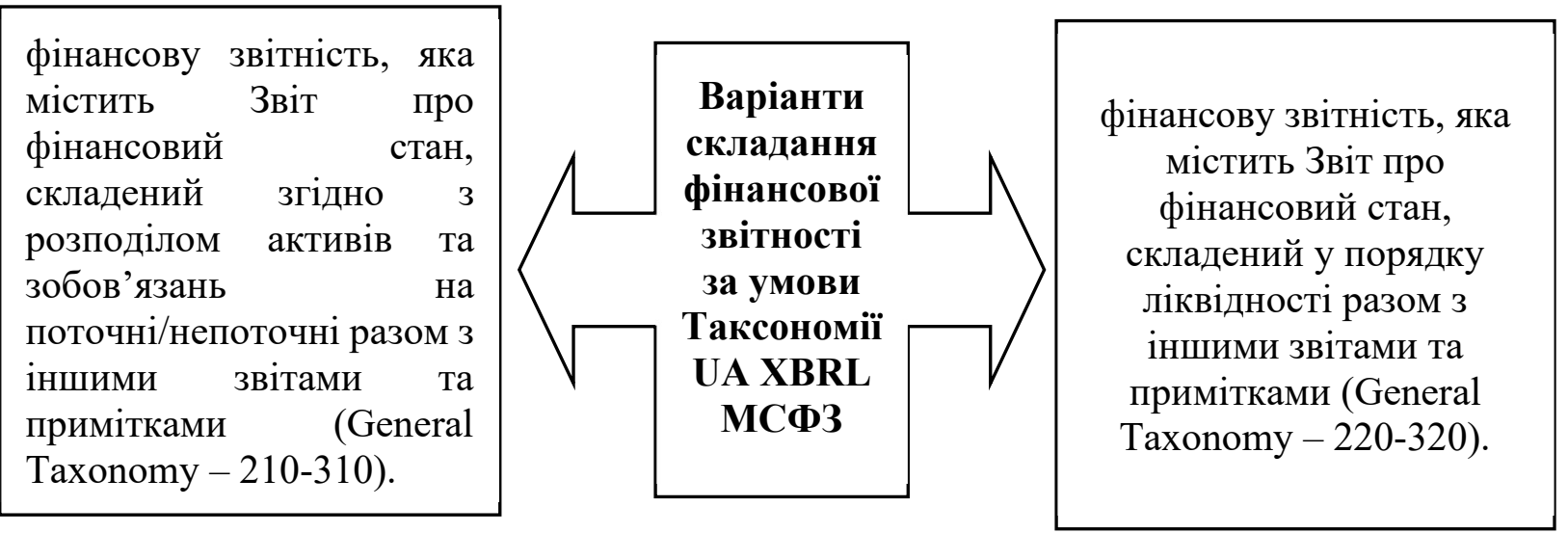

Рис. 1.2.3. Варіанти складання фінансової звітності для суб'єктів господарювання при застосуванні Таксономії UA XBRL MCФ3

3. Провести валідацію (перевірку) фінансової звітності у форматі iXBRL.

4. Підписати файл з фінансовою звітністю у форматі iXBRL.

Поряд 3 цим практикою виробилося два основні підходи до застосування таксономії UA XBRL MCФЗ та створення IXBRL-файлів:

1) підхід, що базується на заповненні стандартних таблиць;

2) підхід, що базується на тегуванні вже підготовленої фінансової звітності.

Сутність, переваги і недоліки цих підходів розглянемо у табл. 1.2.1 
Сутність, переваги і недоліки підходів застосування таксономії UA XBRL MCФЗ та створення iXBRL-файлів

\begin{tabular}{|c|c|c|}
\hline Підхід та його сутність & Переваги & Недоліки \\
\hline $\begin{array}{l}\text { 1. Підхід, що базується на } \\
\text { заповненні стандартних } \\
\text { таблиць передбачає ручне } \\
\text { заповнення тієї інформації, } \\
\text { яка підлягає розкриттю } \\
\text { згідно з вимогами МСФЗ, у } \\
\text { розробленій проформі } \\
\text { фінансової звітності. } \\
\text { Проформа є фіксованою, та } \\
\text { її неможливо змінити }\end{array}$ & 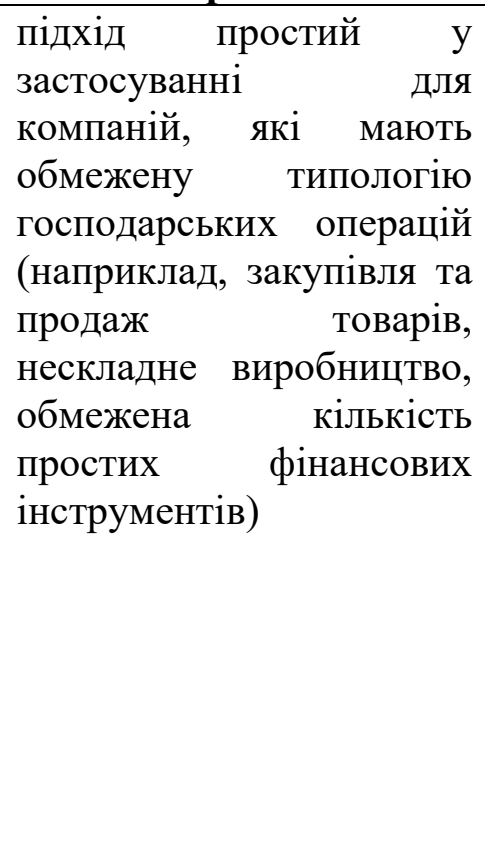 & 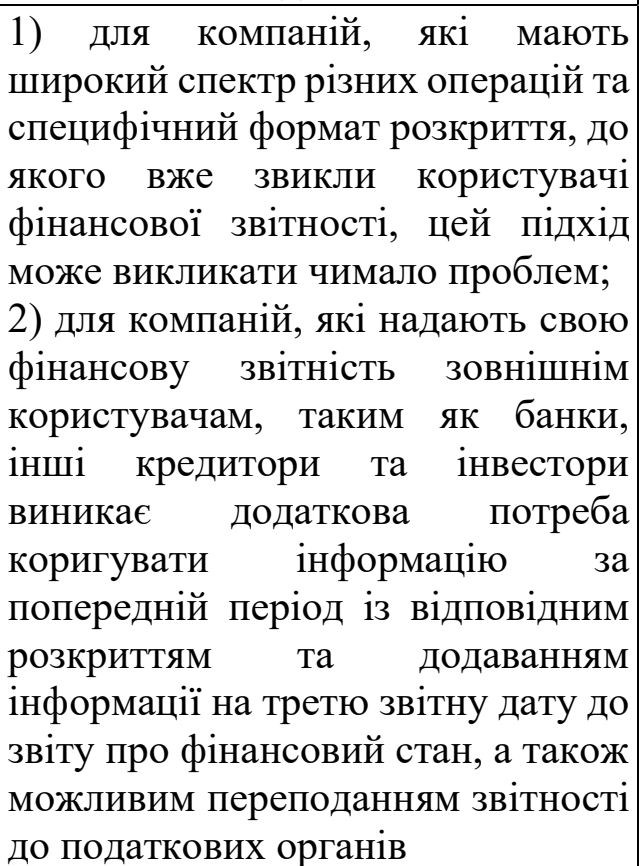 \\
\hline $\begin{array}{l}\text { 2. Підхід, що базується на } \\
\text { тегуванні вже підготовленої } \\
\text { фінансової звітності } \\
\text { передбачає присвоєння тегів } \\
\text { до певних цифр у фінансовій } \\
\text { звітності }\end{array}$ & $\begin{array}{l}\text { 1) дозволяє компанії } \\
\text { врахувати особливості та } \\
\text { специфіку її операцій; } \\
\text { 2) можливість зробити } \\
\text { тегінг фінансової } \\
\text { звітності один раз і } \\
\text { використовувати його } \\
\text { надалі для звітностей за } \\
\text { наступні роки } \\
\text { необхідними } \\
\text { оновленнями; } \\
\text { 3) немає необхідності } \\
\text { змінювати презентацію у } \\
\text { фінансовій звітності }\end{array}$ & $\begin{array}{l}\text { виникнення } \text { окремих труднощів, } \\
\text { зумовлені тим, що таксономія та } \\
\text { розкриті рядки фінансової } \\
\text { звітності можуть не збігатися }\end{array}$ \\
\hline
\end{tabular}

Джерело: складено на основі [21]

Ці підходи є принципово різними з точки зору процесу підготовки та вимагають різного програмного забезпечення, але їх застосування забезпечує один і той самий результат - iXBRL-файл, що є основним і необхідним при складанні фінансової звітності у форматі іXBRL.

Вибір того чи іншого підходу в першу чергу залежить від типу підприємства, специфіки його фінансово-господарської діяльності, характеру і искладності господарських операцій тощо. 
Підприємство може створити фінансову звітність у форматі iXBRL тільки за допомогою спеціального програмного забезпечення, яке воно може або розробити самостійно, або скористатися вже розробленими програмними продуктами (рис. 1.2.2).

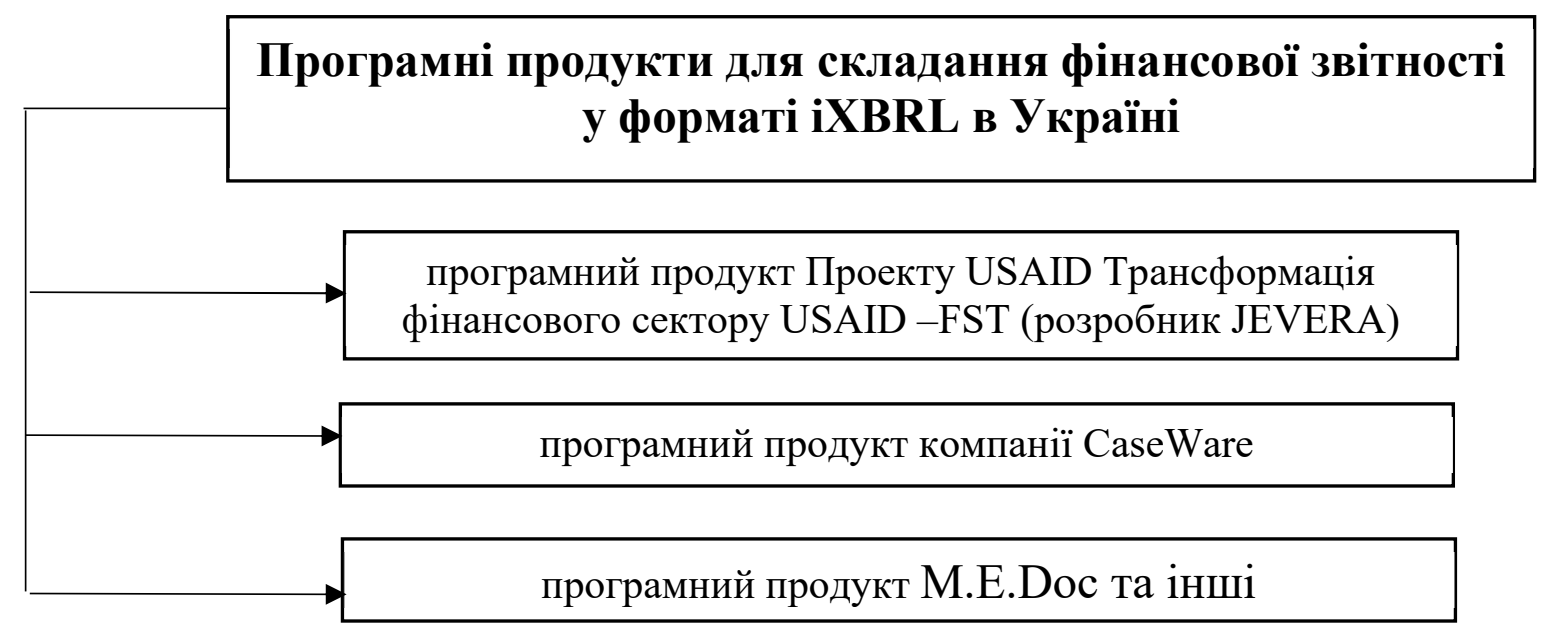

Рис. 1.2.2. Програмні продукти для складання фінансової звітності у форматі iXBRL в Україні

Основними функціями розглянутого програмного забезпечення є:

1) створення фінансового звіту;

2) редагування та видалення фінансового звіту;

3) управління формами звітності у звіті;

4) налаштування вмісту форми;

5) внесення даних до форми звітності;

6) очищення даних звіту та форми звітності;

7) імпорт даних у форматах CSV i JSON;

8) генерація звіту у форматі iXBRL;

9) імпорт даних з іXBRL.

Увесь процес складання фінансової звітності з використанням відповідного програмного забезпечення зводиться до таких етапів:

1. Внесення основної інформації про суб’єкт звітності.

2. Вибір типу звітності.

3. Вибір періоду, за який подається звітність. 
4. Вибір форм звітності, тобто звітів та приміток, що будуть включені до звіту.

При внесенні даних до форм фінансової звітності та під час роботи 3 формами, користувач має змогу переглядати інформацію про ту чи іншу статтю для кращого розуміння iї контексту.

Важливим у процесі підготовки фінансової звітності є їі валідація - перевірка правильності складання фінансової звітності і її відповідності правилам валідації, які закладені в Таксономії UA XBRL MCФ3. Вона здійснюється підприємством самостійно до моменту іï подання в СФЗ з використанням спеціалізованого програмного забезпечення. Одним з них є програмний продукт Arelle.

Arelle - це проект, який підтримується спільнотою XBRL має зручну платформу з відкритим кодом для XBRL. Програмне забезпечення підтримує XBRL та його функціональні розширення в розгорнутому вигляді [20]. Arelle використовується як настільний додаток із можливістю інтеграції 3 іншими програмами та мовами з використанням його веб-сервісів. Адже функціонал його програмного забезпечення $є$ простим і надійним.

У процесі валідації фінансової звітності доречно керуватися такими принципами:

1) заповнення звітів по одному;

2) перевірка кожного звіту окремо;

3) додавання кожного перевіреного звіту до основного i проведення повторної перевірки усього звіту.

Останнім етапом подання фінансової звітності у форматі iXBRL $є$ iï підписання з використанням діючого електронного цифрового підпису (ЕЦП).

Після того, як системою буде надіслано сповіщення користувачам щодо можливості подання фінансової звітності за відповідний звітний період відповідним суб'єктом звітування відбувається подання фінансової звітності шляхом завантаження підготовлених файлів фінансової звітності до Єдиної системи фінансової звітності. 
Першим звітним періодом для звітування за міжнародними стандартами на підставі таксономії за МСФЗ в електронній формі, є 2020 рік. Тобто підприємства, які подають звітність за МСФЗ, будуть звітувати на підставі таксономії за МСФ3 вперше у 2021 році за період 2020 року.

Нещодавно (9 квітня 2021 р.) на засіданні Комітету з управління системою фінансової звітності, створеного відповідно до Меморандуму [17] було схвалено електронний формат Таксономії UA XBRL MCФ3 2020 року (версія 1.2) для використання суб'єктами звітування при складанні фінансової звітності в електронному форматі за 2020 рік та проміжної фінансової звітності в 2021 році.

Для збору фінансової звітності, складеної на основі Таксономії UA XBRL МСФ3, а також з метою забезпечення доступу до неї органів державної влади, інших органів і користувачів створено Центр збору фінансової звітності, що є програмно-технічним комплексом (сукупністю апаратно-технічних і програмних засобів). Завдяки ньому забезпечується:

1) збір фінансової звітності, складеної на основі Таксономії UA XBRL MCФ3;

2) оприлюднення у публічній базі даних (на сайті https://frs.gov.ua) цієї фінансової звітності;

3) створення та підтримання функціонування «кабінетів користувачів» (зокрема, веб-застосунків для підприємств, які подають фінансову звітність);

4) доступ органів державної влади, інших органів і користувачів до поданої підприємствами фінансової звітності тощо [16].

Проведене дослідження дозволяє визначити, що перехід підприємств України на складання і подання звітності на основі Таксономії UA XBRL MCФ3 має багато переваг, основними з яких є посилення прозорості фінансової звітності та підвищення інвестиційної привабливості українських суб'єктів бізнесу шляхом подання ними структурованих фінансових даних в єдиному електронному форматі, який є порівнянним і сумісним із європейськими та міжнародними стандартами. Все це сприятиме пришвидшенню процесу гармонізації обліку, звітності та аудиту в Україні. 